\title{
A field study on characteristics and diversity of gene expression in the liver of dairy cows during the transition period
}

\author{
M. Graber, ${ }^{\star} †$ S. Kohler,† T. Kaufmann,‡ M. G. Doherr,§ R. M. Bruckmaier, ${ }^{*}$ and H. A. van Dorland ${ }^{* 1}$ \\ *Veterinary Physiology, Vetsuisse Faculty, University of Bern, Bremgartenstrasse 109a, 3001 Bern, Switzerland \\ †Swiss College of Agriculture, Länggasse 85, 3052 Zollikofen, Switzerland \\ †Clinic for Ruminants, Vetsuisse Faculty, University of Bern, Bremgartenstrasse 109a, 3001 Bern, Switzerland \\ §Veterinary Public Health Institute, Vetsuisse Faculty, University of Bern, Schwarzenburgstrasse 155, 3097 Liebefeld, Switzerland
}

\begin{abstract}
Metabolic and endocrine adaptations to support milk production during the transition period vary between individual cows. This variation between cows to adapt to lactation may have a genetic basis. The present field study was carried out to determine hepatic adaptations occurring from late pregnancy through early lactation by measuring mRNA abundance of candidate genes in dairy cows on-farm. Additionally, the objective was to observe the diversity in inter-individual variation for the candidate genes that may give indications where individual adaptations at a molecular level can be found. This study was carried out on-farm including 232 dairy cows (parity >3) from 64 farms in Switzerland. Blood and liver samples were collected on $\mathrm{d}$ $20 \pm 7$ before parturition, on $\mathrm{d} 24 \pm 2$, and on $\mathrm{d} 89$ \pm 4 after parturition. Blood plasma was assayed for concentrations of glucose, nonesterified fatty acids, $\beta$-hydroxybutyrate, cholesterol, triglycerides, urea, albumin, protein, insulin, insulin-like growth factor-1, leptin, 3,5,3'-triiodothyronine, and thyroxine. Liver samples were obtained at the same time points and were measured for mRNA abundance of 26 candidate genes encoding enzymes and nuclear receptors involved in gluconeogenesis, fatty acid $\beta$-oxidation, fatty acid and triglyceride synthesis, ketogenesis, citric acid cycle, cholesterol synthesis, and the urea cycle. The cows in the present study experienced a marked metabolic load in early lactation, as presented by changes in plasma metabolites and hormones, and responded accordingly with upregulation and downregulation of almost all candidate genes involved in metabolic processes in the liver. The observed inter-individual variation for the candidate genes, which was highest for acetyl-CoAcarboxylase and glycerol-3-phosphate dehydrogenase 2, should be further investigated to unravel the regulation
\end{abstract}

Received March 16, 2010.

Accepted July 8, 2010.

${ }^{1}$ Corresponding author: anette.vandorland@physio.unibe.ch at molecular level for optimal adaptive performance in dairy cows.

Key words: liver, metabolic adaptation, diversity, dairy cow

\section{INTRODUCTION}

The liver plays a pivotal role during the transition period, and its functioning in accordance with the demand of the cow is a prerequisite for successful adaptation, without the occurrence of health disorders. Several investigations have shown that the physiological, metabolic, and endocrine adaptations to support milk production in early lactation vary between individual cows (Jorritsma et al., 2000; Kessel et al., 2008; van Dorland et al., 2009). Jorritsma et al. (2001) concluded that high serum NEFA and low serum glucose and urea in early lactating dairy cows are significant indicators of hepatic lipidosis. Furthermore, it was shown that ketosis is associated with an increased risk for left-displaced abomasum (Correa et al., 1993) and that ketone bodies impair the function of immune cells in blood (Suriyasathaporn et al., 1999) and in milk (Klucinski et al., 1988). Cows with an optimal adaptive performance, with no occurrence of health disorders, would be most interesting to select for breeding programs aimed at breeding for metabolic robustness in dairy cows. Hence, the variation between cows to adapt successfully to lactation may have a genetic basis (Ingvartsen et al., 2003; Drackley et al., 2005). Parameters as mentioned above have been identified as indicators for metabolic imbalance and adaptive performance (Hachenberg et al., 2007), but no indicators have yet been identified at the molecular level in the liver that play a central role during metabolic adaptation from late gestation to early lactation. At present, gene expression data are increasingly used to investigate mechanisms underlying some physiological functions and to explain the associated phenotypic variability. The importance of gene expression data for the understanding of physiological processes, and potentially to be included in "expressionassisted selection" (Kadarmideen et al., 2006), is obvi- 
ous. Complementary to the classical animal breeding with selection based on phenotype characteristics, the integrated use of molecular data promises a new dimension in animal breeding (Kadarmideen et al., 2006). The combination of gene expression and other genetics data (phenotypic and genotypic) may aid in dissecting complex traits or disease phenotypes. Even though molecular adaptations in the liver of dairy cows have been studied by several researchers (Greenfield et al., 2000; Loor et al., 2005; van Dorland et al., 2009), these studies did not include a large number of cows under field conditions to investigate the individual variation that may exist in gene expression between cows on farm that can be exploited in breeding programs.

The present field study was carried out to increase the understanding of hepatic adaptations occurring from late pregnancy through early lactation by measuring mRNA abundance of candidate genes in a large number of dairy cows on-farm. The present study focused specifically on dairy cows that showed high fat mobilization in their previous lactation, and were therefore likely exposed to elevated metabolic stress during transition, which required major metabolic adjustments. The metabolic processes in focus were gluconeogenesis, fatty acid $\beta$-oxidation, fatty acid and triglyceride synthesis, ketogenesis, citric acid cycle, cholesterol synthesis, and the urea cycle. The research hypothesis tested was that adaptation to lactation, as characterized by changes in plasma metabolites and hormones, involves changes in mRNA expression of the selected candidate genes underlying metabolic processes in the liver. Furthermore, the objective was to study the diversity of interindividual variation for the candidate genes that may indicate where individual adaptations at a molecular level can be found.

\section{MATERIALS AND METHODS}

The experimental procedures of this field study followed the Swiss law on animal protection and were approved by the committees for the permission of animal experiments in the cantons of Bern, Lucerne, and Vaud, Switzerland.

\section{Selection of Cows}

The field study included 232 multiparous dairy cows of the breed types Brown Swiss $(\mathrm{n}=98)$, Red Holstein $(\mathrm{n}=74)$, Swiss Fleckvieh (Simmental $\times$ Red Holstein, $\mathrm{n}=42)$, and Holstein-Friesian $(\mathrm{n}=18)$, and was carried out in Switzerland from October 2007 to July 2008. The cows had a mean 305-d milk yield of 7,542 $\pm 99 \mathrm{~kg}$ (mean $\pm \mathrm{SEM}$ ) in their previous lactation. The selec- tion procedure was based on milk control information from the Brown Swiss and Fleckvieh breeding federations in Switzerland, and included only cows of parity 2 to 13 . Heifers were excluded from the study because cows starting their first lactation have, apart from milk synthesis, additional energy requirements for growth. Therefore, their metabolic regulation may not be similar to that of older cows. Milk yield and composition data from the first 2 milk controls between 9 and 61 DIM were used for the selection of the cows. Cows with a milk fat content of $>45 \mathrm{~g} / \mathrm{L}$ and a fat:protein ratio of $>1.5$ during at least 1 of the 2 milk controls were selected for the study. Both traits reflect the extensive mobilization of body fat and hence are evidence for a considerable metabolic load. Besides the above criteria, selected cows had to calve between mid November 2007 and mid April 2008. During this period, dairy cows were fed predominantly grass and maize silage-based rations with additional concentrates. Finally, farms with at least 2 selected cows were included in the study. This resulted in 64 farms participating in the study.

\section{Blood Collection and Analyses of Plasma Metabolites and Hormones}

The intention was to collect samples at the beginning and at the end of the transition period, during which most metabolic changes occur, and at a time point beyond the peak of lactation. Practically, this resulted in sampling blood in wk 3 prepartum $[20 \pm 7 \mathrm{~d}$ prepartum; $-3 \mathrm{wk}$ ), in wk 4 postpartum ( $24 \pm 2 \mathrm{~d}$ postpartum; +4 wk), and in wk 13 postpartum (89 $\pm 4 \mathrm{~d}$ postpartum; +13 wk), respectively. Blood was sampled from the coccygeal vein between $0900 \mathrm{~h}$ and $1400 \mathrm{~h}$ using evacuated tubes containing tri-potassium-EDTA, and sodium fluoride/tri-potassium-EDTA (for the analysis of glucose concentration). Blood samples were immediately cooled to $5^{\circ} \mathrm{C}$. Tubes were then centrifuged for $15 \mathrm{~min}$ at $3,500 \times g$. Plasma for the determination of metabolites and hormones was stored at $-20^{\circ} \mathrm{C}$ until analyzed. Plasma concentrations of metabolites were measured enzymatically by using kits as described by Vicari et al. (2008). Concentrations of glucose, total cholesterol, triglycerides, albumin, proteins, and urea were measured with kits from BioMérieux, Marcy l'Etoile, France (nos. 61270, 61219, 61236, 61051, 61602, and 61974, respectively). Concentrations of NEFA were measured with kit no. 994-75409 from Wako Chemicals (Neuss, Germany), and that of BHBA with kit no. RB1007 from Randox Laboratories Ltd. (Ibach, Switzerland). Plasma insulin, IGF-I, 3,5,3'-triiodothyronine $\left(\mathbf{T}_{\mathbf{3}}\right)$, and thyroxine $\left(\mathbf{T}_{4}\right)$ were measured by RIA as described by Vicari et al. (2008). Leptin was measured using an 
enzyme immunoassay with the antibody against bovine leptin kindly provided by Helga Sauerwein, University of Bonn, Germany (Sauerwein et al., 2004).

\section{Liver Tissue Collection, mRNA Extraction, and Quantitative Real-Time RT-PCR}

Liver samples were obtained by blind percutaneous needle biopsy (Tru-Cut biopsy needle, Provet, Switzerland) under local anesthesia following blood sampling in $-3 \mathrm{wk},+4 \mathrm{wk}$, and $+13 \mathrm{wk}$. Liver tissue $(60-100$ mg) was directly placed into an RNA stabilization reagent (RNAlater, Ambion, Austin, TX) and kept at $5^{\circ} \mathrm{C}$ for $24 \mathrm{~h}$, and thereafter stored at $-80^{\circ} \mathrm{C}$ until analyzed. Total RNA was isolated from liver samples using peqGOLD TriFast (PEQLAB Biotechnologie GmbH, Erlangen, Germany) according to the manufacturer's instructions. The yield and purity of total RNA were detected by spectrophotometer with a BioPhotometer (Vaudaux-Eppendorf, Basel, Switzerland). Integrity of RNA was verified by the optical density (OD)260/ OD280 absorption ratio, which was between 1.9 and 2.2 for all samples.

For reverse transcription, $1 \mu \mathrm{g}$ of extracted total RNA was reverse transcribed with $200 \mathrm{U}$ of Moloney murine leukemia virus reverse transcriptase RNAase $\mathrm{H}$ Minus, Point Mutant (Promega Corp., Madison, WI) using 100 pmol of random hexamer primers (Invitrogen, Leek, the Netherlands). The obtained cDNA was diluted to a final concentration of $25 \mathrm{ng} / \mu \mathrm{L}$.

The genes selected for measurement encode enzymes involved in major metabolic processes in the liver, including gluconeogenesis, fatty acid $\beta$-oxidation, fatty acid and triglyceride synthesis, ketogenesis, critic acid cycle, cholesterol synthesis, and urea cycle (Table 1). In addition, gene expression was measured for several nuclear receptors (Table 1) related to glucose and lipid metabolism. The primers for the parameters mitochondrial phosphoenolpyruvate carboxykinase (PEPCKm), cytosolic phosphoenolpyruvate carboxykinase (PEP$\mathbf{C K c}$ ), and pyruvate carboxylase (PC) were according to Hammon et al. (2003), and those of acyl-CoA dehydrogenase very long chain (ACADVL), acyl-CoA synthetase long-chain (ACSL), carnitine palmitoyltransferase (CPT) 1A and 2, citrate synthase (CS), 3-hydroxy-3-methylglutaryl-coenzyme A synthase 2 (HMGCS2), and peroxisome proliferator-activated receptor $\alpha$ (PPAR $\alpha)$ were according to van Dorland et al. (2009). For the remaining parameters, intronspanning primers were designed to amplify cDNA (Table 1).

The PCR quantification was performed with the Roter-Gene 6000 (Corbett Research, Sydney, Australia), using software version 1.7.40. Fluorescence take-off was calculated with the "second derivative maximum" program option. A master mix of the following reaction components was prepared: $1.8 \mu \mathrm{L}$ of water, $1.0 \mu \mathrm{L}$ of forward primer $(5 \mathrm{pmol}), 1.0 \mu \mathrm{L}$ of reverse primer $(5$ pmol), $0.2 \mu \mathrm{L}$ of $50 \times$ SYBR-Green $(20 \mathrm{pmol})$ and 5.0 $\mu \mathrm{L}$ of $2 \times$ SensiMix $(1 \mathrm{mM} \mathrm{MgCl} 2 ; 2 \times$ SensiMix NoRef DNA Kit). Nine microliters of master mix and $1 \mu \mathrm{L}$ of sample volume, containing $25 \mathrm{ng}$ of cDNA, were used. The following 3-step PCR program was used: denaturation for $10 \mathrm{~min}$ at $95^{\circ} \mathrm{C}, 40$ cycles of amplification [each consisting of $15 \mathrm{~s}$ at $95^{\circ} \mathrm{C}$, the primer-specific annealing temperature for 30 s (see Table 1 ), and extension at $72^{\circ} \mathrm{C}$ for $20 \mathrm{~s}$, and quantification of fluorescence], and finally a melting curve program $\left(60-95^{\circ} \mathrm{C}\right)$. The mRNA expression levels were calculated relative to the average mRNA levels of the 3 reference genes, GAPDH, $\beta$-actin, and ribosomal protein S9. The mRNA levels of the housekeeping genes were stable across time points (mean \pm SEM, $15.6 \pm 0.06,15.3 \pm 0.04$, and 15.5 \pm 0.04 in -3 wk, +4 wk and +13 wk, respectively). Intron-spanning primers were designed for ribosomal protein S9 and are shown in Table 1. The sequences of primers used for amplification of GAPDH and $\beta$-actin were identical to those of Hammon et al. (2003).

\section{Statistical Analysis}

Data on plasma metabolites and hormones were analyzed with the MIXED procedure of SAS (SAS Institute, 2001), including time, breed type, and parity $(3,4,5$, and $\geq 6$ at the time of the second and third sampling) as fixed effects. The 3 sampling time points $(-3 \mathrm{wk},+4 \mathrm{wk}$, and $+13 \mathrm{wk})$ were treated as repeated factor within subjects (animals), with animals nested within farms. Multiple comparisons between the means at each sampling time point were performed by the Bonferroni's $t$-test, and differences between means were considered significant if $P<0.05$. Breed type and parity were included in the model, because they explained part of the variation for most of the observed parameters.

Expression data were calculated by subtracting crossing points of samples in -3 wk (difference 1 ) and +4 wk (difference 2) from the crossing point value determined for the +13 wk biopsy (Table 2 ). The calculated differences in mRNA expression were analyzed with a similar model as described above including difference in mRNA expression (difference 1 and 2), breed type, and parity as fixed effects. The differences in mRNA expression were treated as repeated factor within subjects (animals), with animals nested within farms. Multiple comparisons between the means of the differences in mRNA expression were performed by using Bonferroni's $t$-test and were considered significant if $P<0.05$. 
Table 1. Polymerase chain reaction primer information ( $f \circ r=$ forward; rev $=$ reverse), annealing temperature, and PCR product length

\begin{tabular}{|c|c|c|c|c|}
\hline Gene $^{1}$ & Sequence $5^{\prime}-3^{\prime}$ & $\begin{array}{l}\text { GenBank } \\
\text { accession no. }\end{array}$ & $\begin{array}{c}\text { Annealing } \\
\text { temperature, } \\
{ }^{\circ} \mathrm{C}\end{array}$ & $\begin{array}{l}\text { Length, } \\
\text { bp }\end{array}$ \\
\hline ACADM for & GTGGAGGTCTTGGACTTG & NM_0010752235 & 61 & 176 \\
\hline ACADM rev & ATGGCTCCTCAGTCATTCTC & & & \\
\hline ACADVL for & TCCCCAAACTGGCATCTGGG & BC_103104 & 60 & 275 \\
\hline ACADVL rev & ATGGGTGACGCCGCCAAAGC & & & \\
\hline $\mathrm{ACoC}$ for & CTCTTCCGACAGGTTCAAGC & AJ_132890 & 61 & 248 \\
\hline $\mathrm{ACoC}$ rev & ACCATCCTGGCAAGTTTCAC & & & \\
\hline ACSL1 for & TGACTGTTGCTGGAGACTGG & NM_001076085 & 61 & 199 \\
\hline ACSL1 rev & CAGCCGTCTTTATCCAGAGC & & & \\
\hline ASS1 for & GCGAGAAGGAGCCAAGTATG & NM_173892 & 61 & 177 \\
\hline ASS1 rev & TGCTTCGCATACTCCATCAG & & & \\
\hline $\mathrm{BDH} 2$ for & TGCAACTGTGTGTGTCCAG & NM_001034488 & 58 & 175 \\
\hline BDH2 rev & CAGATTCATCAGAGGCCAAG & & & \\
\hline CPT1A for & CAAAACCATGTTGTACAGCTTCCA & BF039285 & 54 & 111 \\
\hline CPT1A rev & GCTTCCTTCATCAGAGGCTTCA & & & \\
\hline CPT2 for & CAGCCTGCCCAGGCTGCCTAT & BC105423 & 60 & 163 \\
\hline CPT2 rev & AGTGACCAGCTGCTCATGCA & & & \\
\hline CS for & TGGACATGATGTATGGTGG & BC_114138 & 60 & 217 \\
\hline CS rev & AGCCAAGATACCTGTTCCTC & & & \\
\hline FASN for & CTGAGTCGGAGAACCTGGAG & NM_001012669 & 63 & 232 \\
\hline FASN rev & ACAATGGCCTCGTAGGTGAC & & & \\
\hline GPAM for & GAACAGCAGTCGAGTACAAG & NM_001012282 & 60 & 172 \\
\hline GPAM rev & CCATCCAGTCAGTCTGATCA & & & \\
\hline GPD2 for & CTCCCCATTTATCAGCTC & BC148085 & 60 & 196 \\
\hline GDP2 rev & ATTGCTCCCACCAGTTTGTC & & & \\
\hline G6PC for & GCCAACCTACAGATTTCGGTG & NM_001076124 & 58 & 140 \\
\hline G6PC rev & CAATGCCTGACAAGACTCCAG & & & \\
\hline HMGCR & ACCCATGAGCGAGGTGTATC & BC153262 & 63 & 241 \\
\hline HMGCR & TAGTGCTGGCCACAAGACAG & & & \\
\hline HMGCS1 for & TGTACGGCTCCCTGGCTTCTG & BC_102850 & 60 & 313 \\
\hline HMGCS1 rev & CATGTTCCTTCGAAGAGGGAATC & & & \\
\hline HMGCS2 for & TCTGGCCCATCACTCTGCC & NM_001045883 & 60 & 126 \\
\hline HMGCS2 rev & AGTGGGGAGCCTGGAGAAGC & & & \\
\hline LXR $\alpha$ for & CTGCGATTGAGGTGATGCTC & NM_001014861 & 55 & 229 \\
\hline LXR $\alpha$ rev & CGGTCTGCAGAGAAGATGC & & & \\
\hline OTC for & AGGCTTTCCAAGGTTACCAG & AF_134841 & 61 & 185 \\
\hline OTC rev & GGATACCATGACAGCCATG & & & \\
\hline PEPCKc for & ATGACAACTGCTGGTTGGCTC & NM_174737 & 60 & 204 \\
\hline PEPCKc rev & ACATGGTGCGACCCTTCATG & & & \\
\hline PEPCKm for & TACGAGGCCTTCAACTGGCGT & XM_583200 & 60 & 365 \\
\hline PEPCKm rev & AGATCCAAGGCGCCTTCCTTA & & & \\
\hline $\mathrm{PC}$ for & ATCTCCTACACGGGTGACGT & NM_177946 & 60 & 214 \\
\hline PC rev & TGTCGTGGGTGTGGATGTGCA & & & \\
\hline PCCA for & AACGTTTGGCAGCAGAAGAT & XM_865752 & 61 & 189 \\
\hline PCCA rev & TGACAGGGTAGCCAATTTCC & & & \\
\hline PCCB for & GCGACATGTTTGTGGAACAC & NM_001038548 & 61 & 168 \\
\hline PCCB rev & CATGTGCTCCAGACAGGCTA & & & \\
\hline PPAR $\alpha$ for & AGGGCTGCAAGGGTTTCTTTAG & NM_001034036 & 60 & 363 \\
\hline PPAR $\alpha$ rev & TGACGAAAGGCGGGTTGTTGTTG & & & \\
\hline RPS9 for & AAGCTGATCGGCGAGTATG & NM_001101152 & 58 & 140 \\
\hline RPS9 rev & GCATTACCTTCGAACAGACG & & & \\
\hline SREBF1 for & CCAGCTGACAGCTCCATTGA & NM_001113302 & 53 & 67 \\
\hline SREBF1 rev & TGCGCGCCACAAGGA & & & \\
\hline
\end{tabular}

${ }^{1} \mathrm{ACADM}=$ acyl-CoA dehydrogenase medium chain; ACADVL $=$ acyl-CoA dehydrogenase very long chain; $\mathrm{ACoC}=$ acetyl-CoA-carboxylase; ACSL1 = acyl-CoA synthetase long-chain 1; ASS1 = argininosuccinate synthetase 1; $\mathrm{BDH} 2=3$-hydroxybutyrate dehydrogenase 2; CPT1A = carnitine palmitoyltransferase 1A; CPT2 $=$ carnitine palmitoyltransferase $2 ; \mathrm{CS}=$ citrate synthase; FASN $=$ fatty acid synthase; GPAM = glycerol-3phosphate acyltransferase; GPD2 = glycerol-3-phosphate dehydrogenase 2; G6PC = glucose-6-phosphatase; HMGCR = 3-hydroxy-3-methylglutaryl-coenzyme A reductase; HMGCS1 = 3-hydroxy-3-methylglutaryl-coenzyme A synthase 1; HMGCS2 = 3-hydroxy-3-methylglutaryl-coenzyme A synthase 2; LXR $\alpha=$ liver X receptor $\alpha$; OTC $=$ ornithine transcarbamylase; PCCA $=$ propionyl-CoA carboxylase $\alpha$; $\mathrm{PCCB}=$ propionyl-CoA carboxylase $\beta ; \operatorname{PPAR} \alpha=$ peroxisome proliferators-activated receptor $\alpha ; \mathrm{PC}=$ pyruvate carboxylase; PEPCKc $=$ cytosolic phosphoenolpyruvate carboxykinase; PEPCKm $=$ mitochondrial phosphoenolpyruvate carboxykinase; RPS9 = ribosomal protein S9; SREBF1 = sterol regulatory element binding factor 1 . 
Furthermore, comparison of calculated differences at -3 wk and at +4 wk relative to +13 wk was performed with the same model through comparison with the null hypothesis.

The coefficients of variation for RNA abundance of each hepatic parameter were calculated to represent the inter-individual variation among the dairy cows (Table 3).

\section{RESULTS}

\section{Milk Yield, Fat Content, and Fat to Protein Ratio}

Milk control information obtained from the Brown Swiss and Fleckvieh breeding federations in Switzerland included an average milk yield (mean \pm SEM) of 35.1 $\pm 0.44 \mathrm{~kg} / \mathrm{d}$, a milk fat content of $46.4 \pm 0.6 \mathrm{~g} / \mathrm{L}$, and a fat to protein ratio of $1.4 \pm 0.02$ for the selected cows

Table 2. Relative mRNA expression (delta cycle threshold, $\log _{2}$ ) of hepatic parameters in dairy cows relative to mRNA expression in wk 13 postpartum

\begin{tabular}{|c|c|c|}
\hline \multirow[b]{2}{*}{ Parameter $^{1}$} & \multicolumn{2}{|c|}{$\begin{array}{l}\text { Differences of mRNA expression, } \log _{2} \\
\text { (relative to wk } 13 \text { postpartum) }\end{array}$} \\
\hline & 3 wk prepartum & 4 wk postpartum \\
\hline \multicolumn{3}{|l|}{ Gluconeogenesis } \\
\hline PEPCKc & $-0.62 \pm 0.09^{\mathrm{a}}$ & $0.11 \pm 0.05^{\mathrm{c}}$ \\
\hline PEPCKm & $-0.29 \pm 0.07^{\mathrm{a}}$ & $0.18 \pm 0.06^{\mathrm{b}, \mathrm{c}}$ \\
\hline $\mathrm{PC}$ & $-0.27 \pm 0.05^{\mathrm{a}}$ & $0.46 \pm 0.05^{\mathrm{b}, \mathrm{c}}$ \\
\hline $\mathrm{G} 6 \mathrm{PC}$ & $-0.53 \pm 0.09^{\mathrm{a}}$ & $-0.02 \pm 0.04^{\mathrm{c}}$ \\
\hline PCCA & $-0.21 \pm 0.05^{\mathrm{a}}$ & $-0.18 \pm 0.04^{\mathrm{b}}$ \\
\hline PCCB & $-0.29 \pm 0.05^{\mathrm{a}}$ & $-0.41 \pm 0.15^{\mathrm{b}}$ \\
\hline \multicolumn{3}{|l|}{ Fatty acid oxidation } \\
\hline ACSL1 & $-0.11 \pm 0.06$ & $0.27 \pm 0.05^{\mathrm{b}, \mathrm{c}}$ \\
\hline CPT1A & $-0.27 \pm 0.04^{\mathrm{a}}$ & $0.16 \pm 0.04^{\mathrm{b}, \mathrm{c}}$ \\
\hline CPT2 & $-0.22 \pm 0.05^{\mathrm{a}}$ & $0.22 \pm 0.04^{\mathrm{b}, \mathrm{c}}$ \\
\hline ACADM & $-0.28 \pm 0.06^{\mathrm{a}}$ & $-0.09 \pm 0.05^{\mathrm{c}}$ \\
\hline ACADVL & $-0.24 \pm 0.04^{\mathrm{a}}$ & $0.33 \pm 0.03^{\mathrm{b}, \mathrm{c}}$ \\
\hline \multicolumn{3}{|c|}{ Fatty acid and triglyceride synthesis } \\
\hline ATP citrate lyase & $-0.15 \pm 0.08^{\mathrm{a}}$ & $-0.40 \pm 0.07^{\mathrm{b}, \mathrm{c}}$ \\
\hline FASN & $-0.44 \pm 0.13^{\mathrm{a}}$ & $-0.68 \pm 0.09^{\mathrm{b}}$ \\
\hline $\mathrm{ACoC}$ & $-0.64 \pm 0.09^{\mathrm{a}}$ & $-0.67 \pm 0.08^{\mathrm{b}}$ \\
\hline GPAM & $0.19 \pm 0.08$ & $-0.38 \pm 0.07^{\mathrm{b}, \mathrm{c}}$ \\
\hline GPD2 & $0.06 \pm 0.08$ & $-0.17 \pm 0.07^{\mathrm{c}}$ \\
\hline \multicolumn{3}{|l|}{ Citric acid cycle } \\
\hline CS & $-0.16 \pm 0.06^{\mathrm{a}}$ & $0.17 \pm 0.06^{\mathrm{b}, \mathrm{c}}$ \\
\hline \multicolumn{3}{|c|}{ Ketone body synthesis } \\
\hline HMGCS2 & $-0.17 \pm 0.06^{\mathrm{a}}$ & $-0.03 \pm 0.07$ \\
\hline $\mathrm{BDH} 2$ & $-0.05 \pm 0.04$ & $-0.04 \pm 0.04$ \\
\hline \multicolumn{3}{|l|}{ Cholesterol synthesis } \\
\hline HMGCR & $-0.57 \pm 0.13^{\mathrm{a}}$ & $-0.53 \pm 0.10^{\mathrm{b}}$ \\
\hline HMGCS1 & $-0.40 \pm 0.19^{\mathrm{a}}$ & $-0.57 \pm 0.17^{\mathrm{b}}$ \\
\hline \multicolumn{3}{|l|}{ Urea cycle } \\
\hline ASS1 & $-0.41 \pm 0.07^{\mathrm{a}}$ & $-0.05 \pm 0.04^{\mathrm{c}}$ \\
\hline OTC & $0.34 \pm 0.21$ & $-0.26 \pm 0.16^{\mathrm{c}}$ \\
\hline \multicolumn{3}{|l|}{ Nuclear receptors } \\
\hline PPAR $\alpha$ & $-0.11 \pm 0.04^{\mathrm{a}}$ & $-0.26 \pm 0.03^{\mathrm{b}, \mathrm{c}}$ \\
\hline SREBF1 & $0.12 \pm 0.08$ & $-0.41 \pm 0.07^{\mathrm{b}, \mathrm{c}}$ \\
\hline $\operatorname{LXR} \alpha$ & $-0.12 \pm 0.06$ & $-0.36 \pm 0.05^{\mathrm{b}, \mathrm{c}}$ \\
\hline
\end{tabular}

${ }^{a}$ Means of 3 wk prepartum differ significantly $(P<0.05)$ from 13 wk postpartum.

${ }^{\mathrm{b}}$ Means of 4 wk postpartum differ significantly $(P<0.05)$ from 13 wk postpartum.

${ }^{c}$ Means of 3 wk prepartum and 4 wk postpartum are significantly different $(P<0.05)$.

${ }^{1} \mathrm{ACADM}=$ acyl-CoA dehydrogenase medium chain; ACADVL = acyl-CoA dehydrogenase very long chain; $\mathrm{ACoC}=$ acetyl-CoA-carboxylase; ACSL1 = acyl-CoA synthetase long-chain 1 ; ASS1 = argininosuccinate synthetase 1; $\mathrm{BDH} 2=3$-hydroxybutyrate dehydrogenase 2; CPT1A = carnitine palmitoyltransferase 1A; CPT2 $=$ carnitine palmitoyltransferase $2 ; \mathrm{CS}=$ citrate synthase; FASN $=$ fatty acid synthase; GPAM = glycerol-3phosphate acyltransferase; GPD2 = glycerol-3-phosphate dehydrogenase 2; G6PC = glucose-6-phosphatase; HMGCR = 3-hydroxy-3-methylglutaryl-coenzyme A reductase; HMGCS1 = 3-hydroxy-3-methylglutaryl-coenzyme A synthase 1; HMGCS2 = 3-hydroxy-3-methylglutaryl-coenzyme A synthase 2; LXR $\alpha=$ liver X receptor $\alpha ;$ OTC $=$ ornithine transcarbamylase; PCCA $=$ propionyl-CoA carboxylase $\alpha ;$ PCCB $=$ propionyl-CoA carboxylase $\beta ;$ PPAR $\alpha=$ peroxisome proliferators-activated receptor $\alpha ; \mathrm{PC}=$ pyruvate carboxylase; PEPCKc $=$ cytosolic phosphoenolpyruvate carboxykinase; PEPCKm = mitochondrial phosphoenolpyruvate carboxykinase; RPS9 = ribosomal protein S9; SREBF1 = sterol regulatory element binding factor 1 . 
at $21.3 \pm 0.73$ DIM. At $55.5 \pm 0.72$ DIM, an average milk yield (mean $\pm \mathrm{SEM}$ ) of $34.8 \pm 0.47 \mathrm{~kg} / \mathrm{d}$, a milk fat content of $43.0 \pm 0.6 \mathrm{~g} / \mathrm{L}$, and a fat to protein ratio of $1.4 \pm 0.02$ for the selected cows was observed. The mean 305-d milk yield during the lactation of the field study was $7,583 \pm 111 \mathrm{~kg}$.

\section{Plasma Metabolites and Hormones}

Similar patterns of mean concentrations of NEFA and BHBA in dairy cows were observed with lowest $(P$ $<0.05)$ values at $-3 \mathrm{wk}$ and highest values at $+4 \mathrm{wk}$
$(P<0.05$, Figure 1$)$. Mean glucose concentrations were lowest at +4 wk $(P<0.05)$ compared with -3 wk and $+13 \mathrm{wk}$; the latter 2 time points showed similar values (Figure 1). Mean concentrations of plasma urea, albumin, and protein followed a similar pattern with the lowest concentrations at -3 wk $(P<0.05)$ compared with the other time points (Figure 2). Concentrations of plasma urea, albumin, and protein at +4 and +13 wk were similar. Mean plasma concentrations of cholesterol were lowest at $-3 \mathrm{wk}(P<0.05)$ followed by concentrations at $+4 \mathrm{wk}(P<0.05)$; the highest values were observed at +13 wk $(P<0.05$; Figure 3$)$. Mean

Table 3. Coefficients of variation for mRNA abundance (delta cycle threshold, $\log _{2}$ ) of hepatic parameters in dairy cows

\begin{tabular}{|c|c|c|c|}
\hline \multirow[b]{2}{*}{ Gene $^{1}$} & \multicolumn{3}{|c|}{ Time relative to parturition } \\
\hline & $-3 \mathrm{wk}$ & $+4 \mathrm{wk}$ & $+13 \mathrm{wk}$ \\
\hline \multicolumn{4}{|l|}{ Gluconeogenesis } \\
\hline PEPCKc & 4.8 & 3.2 & 3.1 \\
\hline PEPCKm & 8.7 & 8.7 & 6.7 \\
\hline $\mathrm{PC}$ & 4.7 & 4.1 & 4.1 \\
\hline G6PC & 5.1 & 2.7 & 2.4 \\
\hline PCCA & 3.0 & 3.0 & 2.7 \\
\hline PCCB & 3.8 & 10.4 & 2.8 \\
\hline \multicolumn{4}{|l|}{ Fatty acid oxidation } \\
\hline ACSL1 & 3.8 & 3.7 & 3.5 \\
\hline CPT1A & 4.4 & 4.2 & 4.0 \\
\hline CPT2 & 3.4 & 2.7 & 2.9 \\
\hline ACADM & 3.7 & 3.4 & 2.8 \\
\hline ACADVL & 2.5 & 2.5 & 2.4 \\
\hline \multicolumn{4}{|c|}{ Fatty acid and triglyceride synthesis } \\
\hline ATP citrate lyase & 6.0 & 6.1 & 7.3 \\
\hline FASN & 10.6 & 8.6 & 8.9 \\
\hline $\mathrm{ACoC}$ & 12.7 & 11.1 & 10.4 \\
\hline GPAM & 3.9 & 3.8 & 5.3 \\
\hline GPD2 & 11.9 & 9.4 & 11.9 \\
\hline \multicolumn{4}{|l|}{ Citric acid cycle } \\
\hline CS & 5.2 & 5.5 & 5.5 \\
\hline \multicolumn{4}{|c|}{ Ketone body synthesis } \\
\hline HMGCS2 & 4.0 & 4.4 & 3.4 \\
\hline BDH2 & 3.6 & 3.8 & 3.5 \\
\hline \multicolumn{4}{|l|}{ Cholesterol synthesis } \\
\hline HMGCR & 7.2 & 5.8 & 6.2 \\
\hline HMGCS1 & 9.0 & 7.8 & 10.8 \\
\hline \multicolumn{4}{|l|}{ Urea cycle } \\
\hline ASS1 & 4.1 & 3.3 & 2.8 \\
\hline OTC & 11.5 & 7.2 & 9.6 \\
\hline \multicolumn{4}{|l|}{ Nuclear receptor } \\
\hline $\operatorname{PPAR} \alpha$ & 2.6 & 2.8 & 2.6 \\
\hline SREBF1 & 5.4 & 5.2 & 5.3 \\
\hline $\mathrm{LXR} \alpha$ & 4.7 & 4.7 & 4.2 \\
\hline
\end{tabular}

${ }^{1} \mathrm{ACADM}=$ acyl-CoA dehydrogenase medium chain; ACADVL = acyl-CoA dehydrogenase very long chain; $\mathrm{ACoC}=$ acetyl-CoA-carboxylase; ACSL1 = acyl-CoA synthetase long-chain 1; ASS1 = argininosuccinate synthetase 1; $\mathrm{BDH} 2=3$-hydroxybutyrate dehydrogenase 2; CPT1A = carnitine palmitoyltransferase 1A; CPT2 $=$ carnitine palmitoyltransferase 2 ; CS = citrate synthase; FASN = fatty acid synthase; GPAM = glycerol-3phosphate acyltransferase; GPD2 = glycerol-3-phosphate dehydrogenase 2; G6PC = glucose-6-phosphatase; HMGCR = 3-hydroxy-3-methylglutaryl-coenzyme A reductase; HMGCS1 = 3-hydroxy-3-methylglutaryl-coenzyme A synthase 1; HMGCS2 = 3-hydroxy-3-methylglutaryl-coenzyme A synthase 2; LXR $\alpha=$ liver X receptor $\alpha$; OTC $=$ ornithine transcarbamylase; PCCA $=$ propionyl-CoA carboxylase $\alpha ;$ PCCB $=$ propionyl-CoA carboxylase $\beta$; PPAR $\alpha=$ peroxisome proliferators-activated receptor $\alpha ; \mathrm{PC}=$ pyruvate carboxylase; PEPCKc = cytosolic phosphoenolpyruvate carboxykinase; PEPCKm = mitochondrial phosphoenolpyruvate carboxykinase; RPS9 = ribosomal protein S9; SREBF1 = sterol regulatory element binding factor 1 . 




Figure 1. Mean concentrations \pm SEM of NEFA, BHBA, and glucose in dairy cows in wk 3 prepartum $(-3$ wk $)$ and in wk $4(+4$ wk $)$ and $13(+13 \mathrm{wk})$ postpartum. Different letters $(\mathrm{a}, \mathrm{b}, \mathrm{c})$ indicate differences $(P<0.05)$ between the measured time points.

triglyceride concentrations were highest at $-3 \mathrm{wk}$ and decreased to the lowest concentrations in +4 wk. Mean triglyceride concentrations at +13 wk were lower $(P<$ $0.05)$ than values at $-3 \mathrm{wk}$ and higher than those at $+4 \mathrm{wk}(P<0.05 ;$ Figure 3$)$. Mean concentrations of $\mathrm{T}_{3}$ decreased from -3 wk to $+4 \mathrm{wk}$ with significant lowest concentrations at +4 wk compared with the other time points (Figure 4 ). Plasma $\mathrm{T}_{3}$ concentrations at $+13 \mathrm{wk}$ were highest compared with those at -3 wk and +4 wk. In the case of mean plasma concentrations of $\mathrm{T}_{4}$, highest values were observed in -3 wk $(P<0.05)$, followed by values in $+13 \mathrm{wk}(P<0.05)$; the lowest values were observed in +4 wk $(P<0.05$; Figure 4$)$. Plasma concentrations of leptin and insulin were highest at -3 wk $(P<0.05)$ and decreased in +4 wk, and remained unchanged at +13 wk (Figure 5). Plasma concentrations of IGF-I were also highest at -3 wk $(P<0.05)$ and decreased to lowest values at $+4 \mathrm{wk}$ (Figure 5 ).

\section{Parameters Related to Gluconeogenesis}

All parameters related to gluconeogenesis were observed to be lower in mRNA abundance at $-3 \mathrm{wk}$ compared with +13 wk $(P<0.05$; Table 2$)$. In +4 wk, mRNA abundance for PEPCKm, PC, and propionylCoA carboxylase (PCC) $\alpha$ and $\beta$ were higher relative to +13 wk $(P<0.05)$, and all parameters were increased from -3 wk to +4 wk $(P<0.05)$.

\section{Parameters Related to Fatty Acid $\beta$-Oxidation}

Abundance of mRNA of CPT1A, CPT2, acyl-CoA dehydrogenase medium chain (ACADM), and ACADVL were all lower at -3 wk relative to +13 wk $(P<$ $0.05)$. No change was observed for mRNA abundance of ACSL1 at +4 wk compared with +13 wk. At +4 wk, all parameters related to fatty acid oxidation, except for ACADM, had higher mRNA abundance relative to +13 wk $(P<0.05)$. Furthermore, in case of ACSL1, CPT1A, CPT2, and ACADVL, mRNA abundance increased from -3 wk to +4 wk $(P<0.05)$.

\section{Parameters Related to Fatty Acid and Triglyceride Synthesis}

At -3 wk, mRNA abundance of ATP citrate lyase, fatty acid synthase (FASN), and acetyl-CoA-carboxylase (ACoC), was lower relative to +13 wk $(P<$ 0.05 ; Table 2), and mRNA abundance of glycerol-3phosphate acyltransferase (GPAM) and glycerol3-phosphate dehydrogenase 2 (GPD2) was similar compared with $+13 \mathrm{wk}(P<0.05)$. In $+4 \mathrm{wk}$, mRNA abundance of ATP citrate lyase, FASN, ACoC, and GPAM was also lower relative to that at $+13 \mathrm{wk}(P$ $<0.05$; Table 2). The mRNA abundance from $-3 \mathrm{wk}$ to +4 wk was decreased for ATP citrate lyase, GPAM, and GPD2 $(P<0.05)$. 


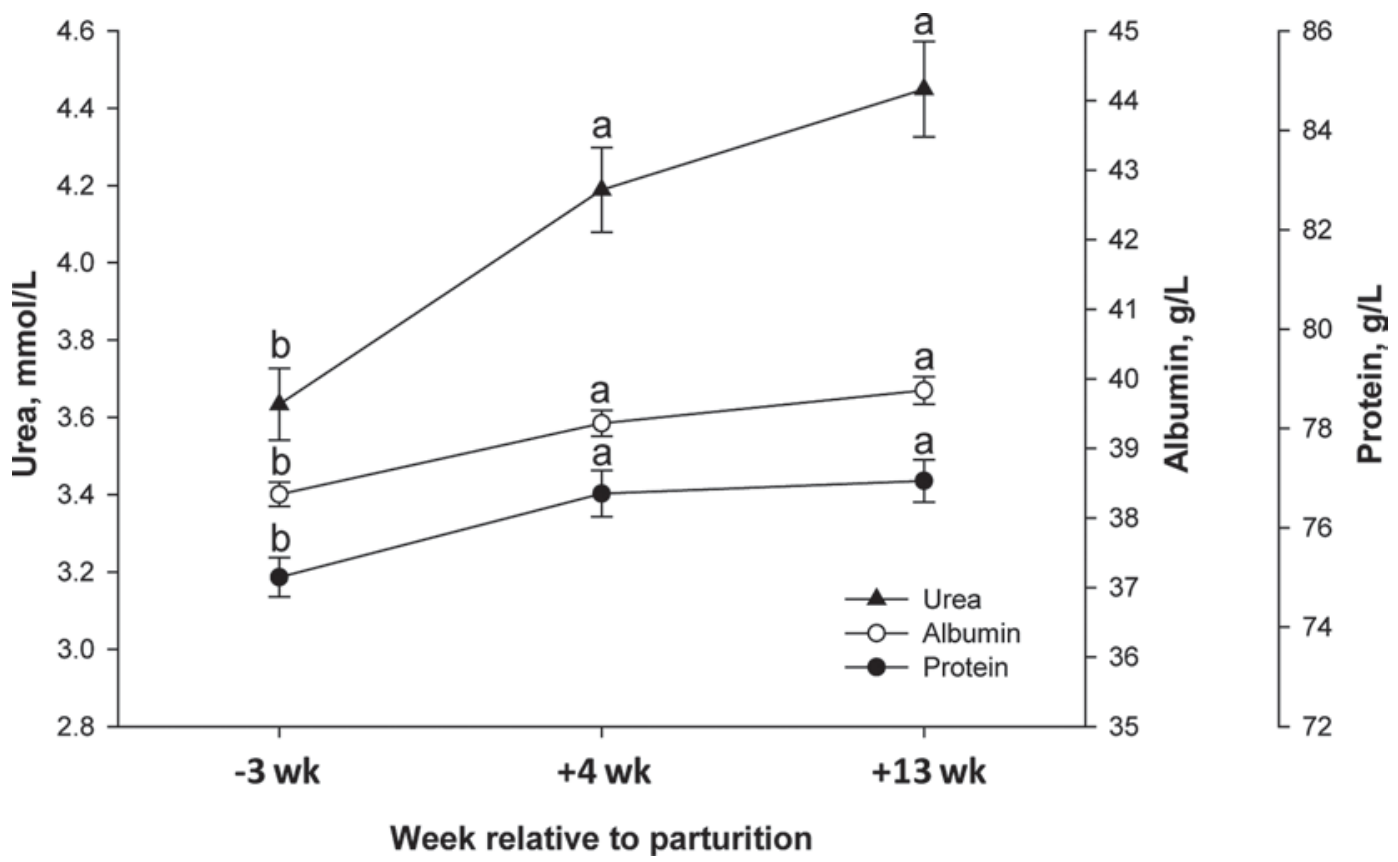

Figure 2. Mean concentrations \pm SEM of urea, albumin, and protein in dairy cows in wk 3 prepartum $(-3$ wk $)$ and in wk $4(+4$ wk $)$ and $13(+13$ wk) postpartum. Different letters $(\mathrm{a}, \mathrm{b})$ indicate differences $(P<0.05)$ between the measured time points.

\section{Parameters Related to Citric Acid Cycle and Ketogenesis}

At -3 wk and +4 wk, changes in mRNA of CS relative to $+13 \mathrm{wk}$, included either an increase or a decrease, respectively $(P<0.05$; Table 2$)$. The mRNA abundance of CS increased from $-3 \mathrm{wk}$ to $+4 \mathrm{wk}(P$ $<0.05)$. The mRNA abundance of HMGCS2 was lower in -3 wk relative to $+13 \mathrm{wk}(P<0.05)$. No significant changes in HMGCS2 mRNA abundance were observed at +4 wk relative to $+13 \mathrm{wk}$, or between $-3 \mathrm{wk}$ and +4 wk. Changes in mRNA abundance of BDH2 between time points were not significant (Table 2).

\section{Parameters Related to Cholesterol Synthesis and Urea Cycle}

At both -3 wk and +4 wk, mRNA abundance of 3-hydroxy-3-methylglutaryl-coenzyme A reductase (HMGCR) and 3-hydroxy-3-methylglutaryl-coenzyme A synthase 1 (HMGCS1) was lower relative to that at +13 wk $(P<0.05$; Table 2$)$. At -3 wk, mRNA abundance of argininosuccinate synthetase 1 (ASS1) was lower, and the mRNA abundance of ornithine transcarbamylase (OTC) was unchanged relative to that at +13 wk $(P<0.05$; Table 2$)$. Furthermore, the mRNA abundance for ASS1 and OTC increased from +4 wk to +13 wk $(P<0.05$; Table 2$)$.

\section{Nuclear Receptors}

For PPAR $\alpha$, lower mRNA abundance was observed in -3 wk compared with +13 wk $(P<0.05)$, and for sterol regulatory element binding factor 1 (SREBF1) and liver $\mathrm{X}$ receptor $\alpha(\mathbf{L X R} \boldsymbol{\alpha})$, no change in mRNA

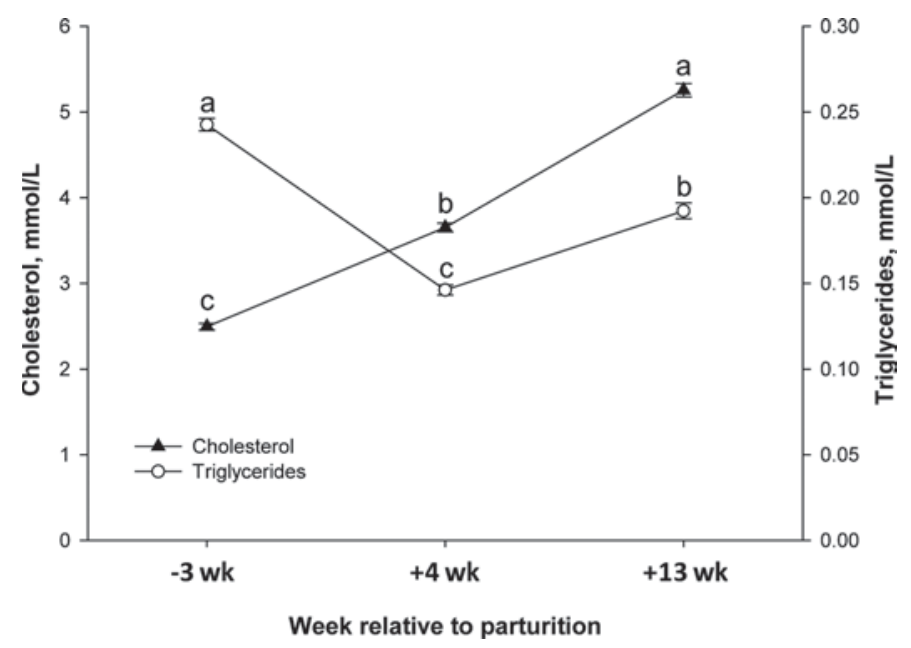

Figure 3. Mean concentrations \pm SEM of cholesterol and triglycerides in dairy cows in wk 3 prepartum $(-3 \mathrm{wk})$ and in wk $4(+4 \mathrm{wk})$ and $13(+13 \mathrm{wk})$ postpartum. Different letters $(\mathrm{a}, \mathrm{b}, \mathrm{c})$ indicate differences $(P<0.05)$ between the measured time points. 


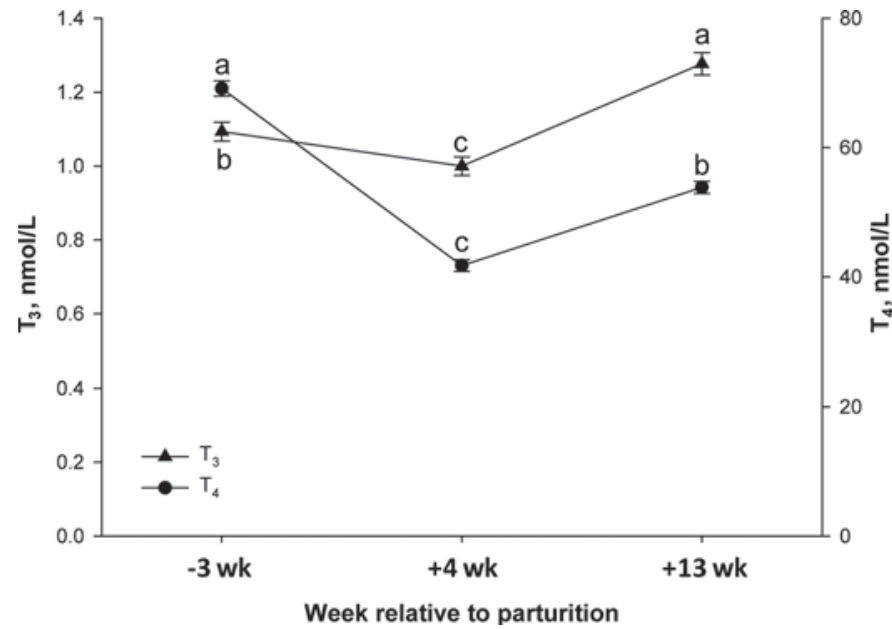

Figure 4. Mean concentrations \pm SEM of 3,5.3'-triiodothyronine $\left(\mathrm{T}_{3}\right)$ and thyroxine $\left(\mathrm{T}_{4}\right)$ in dairy cows wk 3 prepartum $(-3 \mathrm{wk})$ and in wk $4(+4$ wk) and $13(+13 \mathrm{wk})$ postpartum. Different letters $(\mathrm{a}, \mathrm{b}, \mathrm{c})$ indicate differences $(P<0.05)$ between the measured time points.

abundance was observed in -3 wk relative to +13 wk. At $+4 \mathrm{wk}$, lower mRNA abundance was found for PPAR $\alpha$, LXR $\alpha$, and SREBF1 relative to that at +13 wk $(P<0.05)$, and mRNA abundance for PPAR $\alpha$, LXR $\alpha$, and SREBF1 was decreased from -3 wk to +4 wk $(P<0.05)$.

\section{Inter-Individual Variation for mRNA Levels of Parameters Measured in the Liver}

The coefficients of variation for the mRNA abundance of the parameters measured in the liver tissue at each time point represent the inter-individual variation (Table 3). In general, the inter-individual variation of the measured parameters ranged from 2.4 to $12.7 \%$. Highest variation between cows was observed for the mRNA abundance encoding for $\mathrm{ACoC}$ and glycerol3-phosphate dehydrogenase 2 (GPD2; mean across time points of 11.4 and $11.1 \%$, respectively), which are involved in fatty acid and triglyceride synthesis, respectively. The lowest inter-individual variation was calculated for mRNA abundance of ACADVL and PPAR $\alpha$ (mean of 2.5 and $2.7 \%$, respectively). Furthermore, the largest changes in the calculated variation in $\mathrm{CV}$ over time were observed for $\mathrm{PCCB}$, and similar $\mathrm{CV}$ over time were calculated for ACADVL. Figures $6 \mathrm{~A}$ and $6 \mathrm{~B}$ illustrate the distribution of the individual measurements for ACADVL and ACoC. These box plots illustrates that the data are normally distributed and that variation between animals is not more than around 1 unit mRNA abundance (delta CT, log2).

\section{DISCUSSION}

Our study appears to be the first to include a large number of cows $(>200)$ for evaluation of liver metabolism by means of mRNA abundance of genes encoding key parameters involved in metabolic processes around parturition. Gene expression was measured in this study, because the method allowed a large number of genes to be studied from only a small tissue sample, which was easily obtained from cows on-farm. This allowed a more complete image on the regulation of different metabolic pathways in the liver at different functional stages of the mammary gland. Most importantly, the amendment of metabolic characterization at the level of metabolites, hormones, and growth factors by a vast number of parameters at the transcript level provides a more complete image of the parameters significant for adaptation to milk production.

\section{Metabolic State of the Cows as Described by Plasma Parameters}

The plasma concentrations of metabolites and hormones followed patterns observed previously in dairy cows around parturition and in early lactation (Blum et al., 1983; Aeberhard et al., 2001; Kessel et al., 2008). The measured concentrations and the extent of changes of these plasma parameters over the studied period may give an indication of the metabolic state the cows were in during the study period. The lower concentrations of $\mathrm{T}_{3}, \mathrm{~T}_{4}$, glucose, and IGF-I at +4 wk compared with the other time points reflect a poorer energy status of the cows at +4 wk. This is confirmed by the insulin and leptin concentrations, which were also decreased at +4 wk compared with the prepartum level, but remained equally low at +13 wk. Hormonal changes during the periparturient period are important for the shifts in energy metabolism and favor the mobilization of fat from adipose tissue (Aeberhard et al., 2001) and the direct use of most glucose for lactose synthesis (Bauman and Currie, 1980). The poorer energy status in $+4 \mathrm{wk}$, therefore, resulted in higher concentrations of NEFA and BHBA compared with the other time points. Body fat is generally mobilized in response to an energy deficit in the early postpartum period, resulting in increased plasma NEFA concentrations (Emery et al., 1992) and increased BHBA concentrations when the increased uptake of fatty acids in the liver and the acetyl-coA production from fatty acid oxidation exceeds its utilization by the citric acid cycle or lipogenesis (Ballard et al., 1968). The elevated NEFA and BHBA concentrations at +4 wk reflect a higher metabolic load in the 


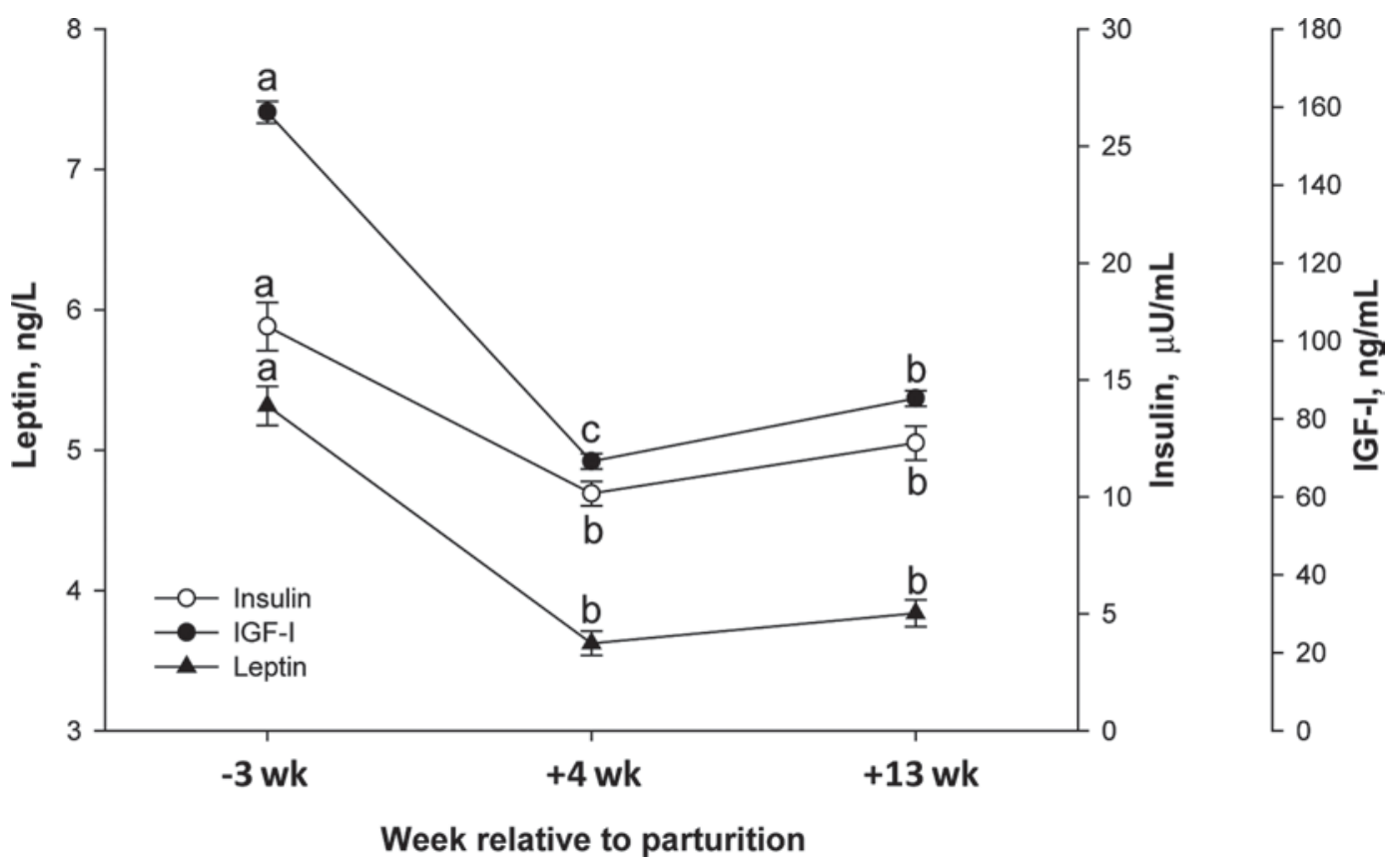

Figure 5. Mean concentrations \pm SEM of leptin, insulin, and IGF-I in dairy cows in wk 3 prepartum $(-3$ wk) and in wk $4(+4$ wk) and 13 $(+13 \mathrm{wk})$ postpartum. Different letters $(\mathrm{a}, \mathrm{b}, \mathrm{c})$ indicate differences $(P<0.05)$ between the measured time points.

dairy cows (Knight et al., 1999) compared with -3 wk and +13 wk. Hence, the mean BHBA concentration at $+4 \mathrm{wk}$ of approximately $1.5 \mathrm{mmol} / \mathrm{L}$ is indicative for subclinical ketosis (Duffield et al., 1997), which generally follows high NEFA concentrations in the first 2 wk of lactation (Grum et al., 1996). Therefore, at +4 wk, NEFA concentrations were overall not as high as those observed in wk 2 after calving (e.g., Grum et al., 1996; Loor et al., 2005). Parallel to the mobilization of body fat, increasing plasma cholesterol concentrations were measured postpartum, as observed in other studies (Arave et al., 1975; Aeberhard et al., 2001), reflecting the changes in lipid and steroid metabolism during decreasing body weight.

As part of the metabolic load, elevated urea concentrations after parturition can be added. High plasma urea concentrations in early lactation are a consequence of high plasma ammonia loads, which can be caused from a high protein diet in early lactation, from a low ratio of fermentable OM:CP in the diet, or from increased endogenous protein breakdown with energy-consuming N-excretion as a consequence (Reynolds et al., 1991).

The metabolic load, furthermore, involved changes in plasma concentrations of triglycerides, protein, and albumin. The decreased triglyceride concentrations at +4 wk compared with prepartum concentrations in the present study reflect the use of triglycerides as an important source of long-chain fatty acids for milk fat synthesis in early lactation (Blum et al., 1983). Changes in plasma protein and albumin concentrations in the present study were similar to those reported by Blum et al. (1983) and Aeberhard et al. (2001). The lower protein concentrations prepartum could be explained by colostrum building in the udder, for which protein is used (Blum et al., 1983).

\section{Gene Expression Changes in the Liver and Associations with Plasma Parameters}

The changes in abundance of mRNA encoding a variety of hepatic candidate genes over time represent specific responses of the liver to the challenge of lactation and the associated metabolic load. The reason for presenting the changes in mRNA abundance over time relative to $\mathrm{wk}+13$ was that this time point is outside the physiological events of the periparturient period, beyond negative energy balance, and beyond the peak of lactation. At 13 wk after calving, dairy cows can be assumed to be in a stable metabolic state.

\section{Gluconeogenesis}

The observed changes in mRNA abundance for PEPCKc, PEPCKm, PC, and glucose-6-phosphatase (G6PC) at -3 wk and +4 wk relative to +13 wk are indicative for the adaptive adjustments in the liver to support the demand for glucose around parturition. In addition, our findings confirm that whole body glucose 

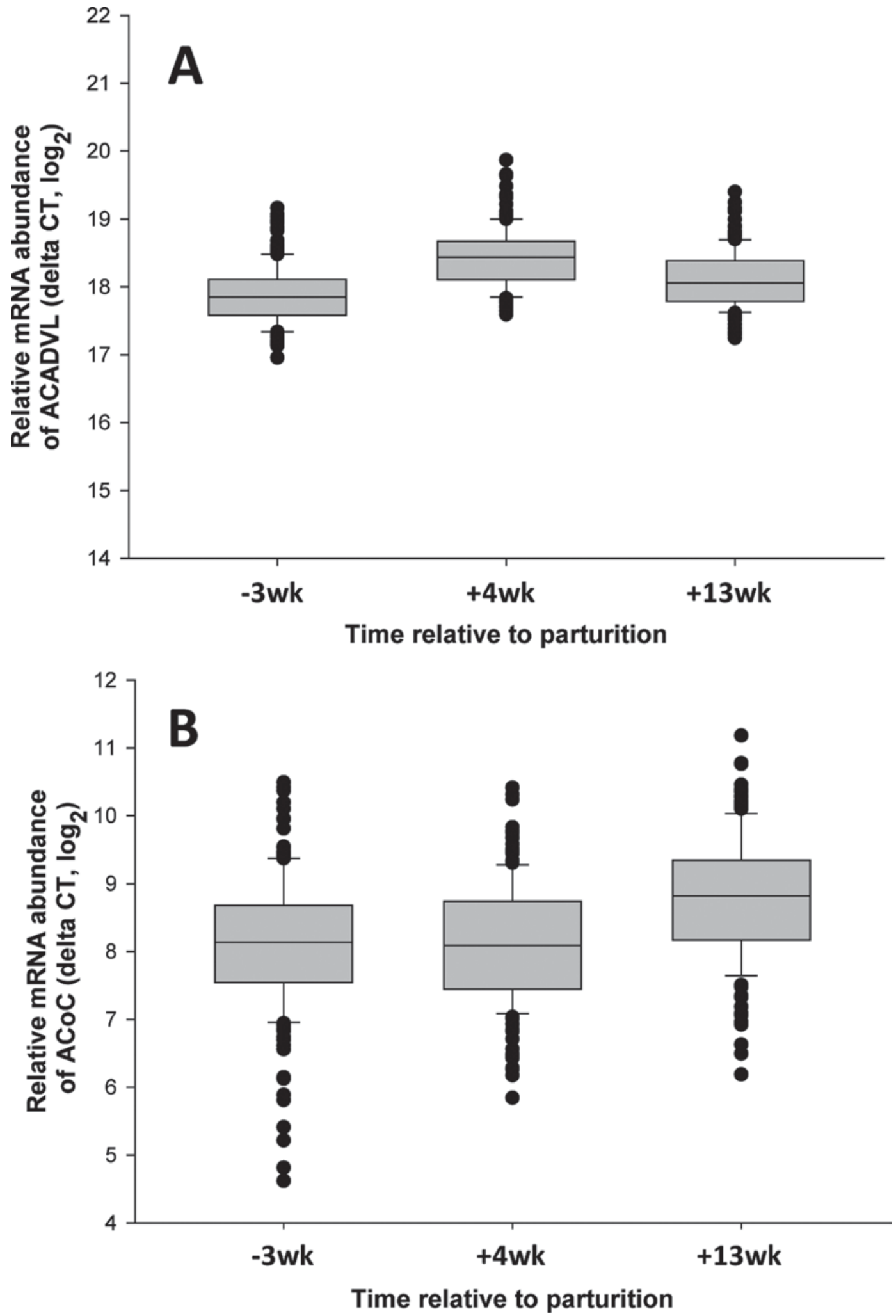

Figure 6. Box plots of mean concentrations of relative mRNA abundance (delta $\mathrm{CT}, \log _{2}$ ) of very long chain acyl-coenzyme A dehydrogenase (ACADVL; A) and of acetyl-CoA-carboxylase (ACoC; B) in wk 3 prepartum $(-3 \mathrm{wk})$ and in wk $4(+4$ wk) and 13 (+13 wk) postpartum. 
turnover is greater in lactating than in gestating cattle and sheep (Baird et al., 1983; Bell, 1995; Reynolds et al., 2003). The significant change in mRNA abundance between $-3 \mathrm{wk}$ and $+4 \mathrm{wk}$ for PEPCKm and PC, observed in the present study, is in agreement with Greenfield et al. (2000), who observed an increased mRNA abundance of PEPCK and PC at +4 wk compared with prepartum levels, suggesting increased metabolism of lactate and amino acids that contribute to the liver pyruvate pool. In addition, Greenfield et al. (2000) observed almost equal mRNA abundance at 4 and $8 \mathrm{wk}$ postpartum for PEPCK and PC. However, in the present study, changes in mRNA abundance of PEPCK and $\mathrm{PC}$ included a decrease from +4 wk to +13 wk. This may indicate that mRNA abundance of PEPCK and PC may decrease at least after $8 \mathrm{wk}$ postpartum. The increase in mRNA abundance of G6PC from prepartum to postpartum followed by a similar mRNA abundance postpartum is in agreement with Rukkwamsuk et al. (1999), who observed an increase in G6PC activity in the first $3 \mathrm{wk}$ after parturition in response to the sudden need for glucose.

Our findings for PCCA and PCCB are in agreement with those of $\mathrm{Xu}$ and Wang (2008). In addition, Murondoti et al. (2004) observed, in cows fed ad libitum prepartum followed by restrictive feeding after parturition, lower enzyme activity of PCC than in control cows fed normally. The enzymes PCCA and PCCB are essential for utilization of propionate, the major gluconeogenic substrate in ruminants. The findings from the present study could therefore indicate insufficient production of glucose, which led to low blood glucose concentrations, likely because of a decreased supply of propionate during the transition period as a result of decreased DMI commonly observed around parturition (Grummer, 1993).

\section{Fatty Acid Oxidation}

An increase of mRNA abundance from -3 wk to +4 wk for ACSL1, CPT1A, CPT2, ACADM, and ACADVL may reflect the increase in oxidation of fatty acids because of an elevated level of NEFA during negative energy balance postpartum (Emery et al., 1992). Subsequently, NEFA is taken up increasingly from the circulation by the liver, which is a concentrationdependent process and not saturated (Zammit, 1983). These findings confirm that whole-body NEFA turnover is greater in lactating than in nonlactating cattle and sheep (Bell, 1995; Drackley, 1999). Furthermore, parallel to the decreased NEFA levels at +13 wk compared with +4 wk, mRNA abundance was decreased for most of the parameters related to fatty acid oxidation. Loor et al. (2005) also observed increased mRNA abundance of ACADVL and ASCL1 in + 4 wk compared with prepartum mRNA abundance. Dann et al. (2000) observed $49 \%$ greater total activity of CPT at $1 \mathrm{~d}$ postpartum than at $21 \mathrm{~d}$ prepartum; activity at $21 \mathrm{~d}$ postpartum was $27 \%$ greater but had returned to prepartum values by d 65 postpartum.

\section{Fatty Acid and Triglyceride Synthesis}

Triglyceride accumulation in the liver may start before parturition. Bertics et al. (1992) found that triglyceride content of liver almost doubled from $17 \mathrm{~d}$ before parturition through $1 \mathrm{~d}$ following parturition. In contrast, in the present study, no change in mRNA abundance was observed for GPAM and GPD2 prepartum relative to that at $+13 \mathrm{wk}$. Therefore, triglyceride accumulation may not start at 4 wk before calving. In the present study, GPAM was downregulated in early lactation compared with the other time points, which is in agreement with Van den Top et al. (1996) and Loor et al. (2006), who explained that a downregulation of GPAM in early lactation in dairy cows is a way to channel NEFA toward fatty acid oxidation. The same explanation may apply to the decreased mRNA abundance of GPD2 (also part of the glycerol-3-phosphate pathway) at +4 wk compared with -3 wk. The lower mRNA abundance for FASN and ACoC at -3 wk and +4 wk compared with +13 wk is in agreement with results from Doepel et al. (2002), who observed these changes in adipose tissue of dairy cows. The change in FAS and ACC reflect the reduced lipogenesis around parturition, mediated in part by low plasma insulin concentrations (Claycombe et al., 1998). Kim et al. (2004) also observed decreased expression of FASN and ACC in the liver of mice used for a long-term high-fat intake-induced obesity study. Even though activities of ATP citrate lyase and citrate synthase in the liver of dairy cows are low (Hanson and Ballard, 1967), the observed significant changes in mRNA over time in the present study does imply their involvement during metabolic adaptation to lactation. Citrate formed in the Krebs cycle is shuttled to the cytosol where it is converted to acetyl-CoA by ATP citrate lyase, after which acetyl-CoA is converted by acetyl-CoA carboxylase 1 into malonyl-CoA (Voet and Voet, 2004). The concentration of malonyl-CoA is regulated by activity of acetyl-CoA carboxylase, which is inactive during insulin-deficient states (Zammit, 1996). This may explain the lower mRNA abundance of ATP citrate lyase at +4 wk compared with that at -3 wk and +13 wk. On the other hand, the increased mRNA abundance of CS at +4 wk compared with prepartum level and 
relative to +13 wk in the present study may reflect an upregulated citric acid cycle during early lactation due to the breakdown of fat, producing large amounts of acetyl-CoA going into the tricarboxylic acid cycle (Lopes-Cardozo et al., 1975). In dairy cows, Murondoti et al. (2004) also observed an increase of CS activity in the liver from prepartum to postpartum.

\section{Ketogenesis, Cholesterol, and Urea Synthesis}

In cow liver in vitro, the 3-hydroxy-3-methylglutarylcoenzyme A pathway (acetoacetate formation from acetoacetyl-CoA in liver cell fractions) was increased during ketosis (Lopes-Cardozo et al., 1975). However, in the present study, at $+4 \mathrm{wk}$, the high plasma BHBA concentrations did not coincide with higher mRNA abundance of HMGCS2 and 3-hydroxybutyrate dehydrogenase 2 (BDH2) compared with the other time points. In the rat, Nadal et al. (2002) observed that insulin inhibits expression of HMGCS2. Zammit (1990) mentioned that low insulin concentrations enhance ketogenesis via effects on hepatic malonyl-CoA. The higher plasma insulin concentrations prepartum may therefore explain the lower mRNA abundance of HMGCS2 at -3 wk relative to +13 wk. However, the change in mRNA abundance of HMGCS2 from $-3 \mathrm{wk}$ to $+4 \mathrm{wk}$, in which similar low insulin concentrations as at +13 wk were measured, was not significant. The mRNA abundance of BDH2 remained unchanged over time. Nielsen and Fleischer (1969) indicated that ruminant liver mitochondria lack BDH. Koundakjian and Snoswell (1970) found similar results for sheep liver, but also established that homogenates of sheep liver do have demonstrable enzyme activity, the enzyme being present in the cytosol.

The downregulation of genes involved in cholesterol synthesis at +4 wk may in part be explained by the low plasma concentrations of insulin, because insulin is known to increase cholesterol synthesis by increasing the activity of HMGCR (Ness and Chambers, 2000). Furthermore, downregulation of HMGCS1 and HMGCR was observed to be associated with feed restriction and ketosis (Loor et al., 2007), which may impair export of very low density lipoprotein and contribute to greater triglyceride accumulation in the liver. This may partly explain the decreased plasma triglycerides concentrations at +4 wk compared with the other time points.

Urea cycle enzyme activities are elevated in response to starvation and high protein diets (Morris, 1992). The catabolic state in early lactation may resemble starvation, and, in the present study, included increased mRNA abundance of ASS1 from prepartum to postpartum. On the other hand, the reduced mRNA abun- dance of OTC in early lactation may reflect decreased ureagenesis due to triglyceride accumulation in the liver (Strang et al., 1998; Zhu et al., 2000). Hartwell et al. (2001) also observed higher prepartum mRNA abundance OTC compared with postpartum. Therefore, our results reflect the differential response of OTC compared with the other urea cycle enzymes, likely because of the hormonal events of early lactation, rather than being due to posttranslational modifications (Morris, 1992).

\section{Nuclear Receptors}

The nuclear receptor PPAR $\alpha$ is a ligand-activated transcription factor that regulates liver lipid and carbohydrate metabolism, and is activated by long-chain fatty acids and their eicosanoid derivatives. However, the mRNA expression of PPAR $\alpha$ did not follow the expected pattern, corresponding to the measured NEFA concentration after parturition as observed in other studies (Janovick et al., 2004; Loor et al., 2005). Janovick et al. (2004) observed an increase in mRNA encoding for PPAR $\alpha$ in the liver of cows around parturition. Loor et al. (2005) detected a marked upregulation of hepatic PPAR $\alpha$ from -14 to 1 DIM that persisted through 49 DIM. On the other hand, our results confirm more recent observations from van Dorland et al. (2009) and Carriquiry et al. (2009). The latter group explained their findings by a possible inflammatory response of the liver, likely due to excessive prepartum caloric intake, which decreased hepatic expression of PPAR $\alpha$ (Loor et al., 2007).

In the present study, changes in mRNA abundance for LXR $\alpha$ and SREBF1 followed a similar pattern with lowest abundance at +4 wk compared with the other time points. Liver $\mathrm{X}$ receptors are now known to be involved in cholesterol, fat, and glucose metabolism, have emerged as integrators of metabolism and inflammatory signaling (Zelcer and Tontonoz, 2006), and were observed to be suppressors of hepatic glucose production (Steffensen and Gustafsson, 2004). Downregulation of LXR $\alpha$ at +4 wk may therefore have allowed increased hepatic gluconeogenesis. Furthermore, the downregulation of SREBF1, FASN, and ACoC at +4 wk relative to $+13 \mathrm{wk}$ is in agreement with the results for LXR $\alpha$, because SREBF1, FASN, and ACoC are targets of LXR $\alpha$ (Steffensen and Gustafsson, 2004). In addition, SREBP1 was observed to be upregulated by insulin in vivo and in primary hepatocyte cultures of the rat (Fleischmann and Iynedjian, 2000), which confirms the low insulin concentrations in early lactation in the present study that accompanied low mRNA abundance for SREBP1. 


\section{Inter-Individual Variation for mRNA Abundance of Hepatic Parameters}

The inter-individual variation for the mRNA abundance of hepatic factors observed seems small, ranging from 2.4 to $12.7 \%$; however, $\mathrm{CV}$ were calculated from gene expression data in a $\log _{2}$ scale. From the distribution of observations for ACADVL and ACoC, it can be seen that the relatively small adjustments at the mRNA level and between animals are obviously related to relatively large phenotypic differences. The highest inter-individual variation (overall mean $>7$ ) was observed for hepatic parameter(s) related to fatty acid and triglyceride synthesis, cholesterol synthesis, gluconeogenesis, and urea cycle. Variation in adaptive performance between cows during the periparturient period may therefore partly be explained by the variation that exists between cows at molecular level for certain metabolic reactions in the liver. This confirms that variation between cows to adapt successfully to lactation may have a genetic basis (Ingvartsen et al., 2003; Drackley et al., 2005). The difference between CV over time in the present study further shows that sampling at time points relative to the functional stage of the mammary gland is important for further investigations to unravel the genetic basis underlying successful adaptation in dairy cows.

\section{CONCLUSIONS}

This appears to be the first on-farm study to investigate the hepatic gene expression of factors related to major metabolic processes in a large number of dairy cows at different time points around parturition. The gene expression data generated by the present study can assist in understanding, together with plasma metabolites and hormones, the physiological events during transition from dry-off to early lactation in dairy cows. The cows in the present study experienced a marked metabolic load in early lactation and responded accordingly with upregulation and downregulation of almost all candidate genes involved in metabolic processes in the liver. The observed inter-individual variation for the candidate genes, which was observed to be highest for acetyl-CoA-carboxylase and glycerol-3-phosphate dehydrogenase 2 , should be further investigated to unravel the regulation at molecular level for optimal adaptive performance in dairy cows.

\section{ACKNOWLEDGMENTS}

We thank the Brown Swiss (Zug, Switzerland) and Fleckvieh (Zug, Switzerland) breeding federations for their assistance during the selection of dairy cows for this field study. The Swiss farmers are thanked for their cooperation in the field study and for providing their cows for sampling. Furthermore, we thank Stefanie Speiser, Olga Wellnitz, Claudine Morel, and Yolande Zbinden (Vetsuisse Faculty, University of Bern, Bern, Switzerland) for their technical support and assistance during sample collection and laboratory analyses. The H. Wilhelm Schaumann Stiftung (Hamburg, Germany) is thanked for their support with a scholarship. This study was supported by Swissgenetics (Zollikofen, Switzerland) and the Swiss Bundesamt für Landwirtschaft (Bern, Switzerland).

\section{REFERENCES}

Aeberhard, K., R. M. Bruckmaier, and J. W. Blum. 2001. Metabolic, enzymatic and endocrine status in high-yielding dairy cows - Part 2. J. Vet. Med. A Physiol. Pathol. Clin. Med. 48:111-127.

Arave, C. W., R. H. Miller, and R. C. Lamb. 1975. Genetic and environmental effects on serum cholesterol of dairy cattle of various ages. J. Dairy Sci. 58:423-427.

Baird, G. D., J. G. van der Walts, and E. N. Bergman. 1983. Wholebody metabolism of glucose and lactate in productive sheep and cows. Br. J. Nutr. 50:249-265.

Ballard, F. J., R. W. Hanson, D. S. Kronenfeld, and F. Raggi. 1968. Metabolic changes in liver associated with spontaneous ketosis and starvation in cows. J. Nutr. 95:160-173.

Bauman, D. E., and W. B. Currie. 1980. Partitioning of nutrients during pregnancy and lactation: A review of mechanisms involving homeostasis and homeorhesis. J. Dairy Sci. 63:1514-1529.

Bell, A. W. 1995. Regulation of organic nutrient metabolism during transition from late pregnancy to early lactation. J. Anim. Sci. 73:2804-2819.

Bertics, S. J., R. R. Grummer, C. Cadorniga-Valino, and E. E. Stoddard. 1992. Effect of prepartum dry matter intake on liver triglyceride concentration and early lactation. J. Dairy Sci. 75:19141922 .

Blum, J. W., P. L. Kunz, H. Leuenberger, K. Gautschi, and M. Keller 1983. Thyroid hormones, blood plasma metabolites and haematological parameters in relationship to milk yield in dairy cows. Anim. Prod. 36:93-104.

Carriquiry, M., W. J. Weber, S. C. Fahrenkrug, and B. A. Crooker. 2009. Hepatic gene expression in multiparous Holstein cows treated with bovine somatotropin and fed n-3 fatty acids in early lactation. J. Dairy Sci. 92:4889-4900.

Claycombe, K. J., B. H. Jones, M. K. Standridge, Y. Guo, J. T. Chun, and J. W. Taylor. 1998. Insulin increases fatty acid synthase gene transcription in human adipocytes. Am. J. Physiol. 274:R1253R1259.

Correa, M. T., H. Erb, and J. Scarlett. 1993. Path analysis for seven postpartum disorders of Holstein cows. J. Dairy Sci. 76:13051312 .

Dann, H. M., G. N. Douglas, T. R. Overton, and J. K. Drackley. 2000. Carnitine palmitoyltransferase activity in liver of periparturient dairy cows. J. Dairy Sci. 83(Suppl. 1):1056. (Abstr.)

Doepel, L., H. Lapierre, and J. J. Kennelly. 2002. Peripartum performance and metabolism of dairy cows in response to prepartum energy and protein intake. J. Dairy Sci. 85:2315-2334.

Drackley, J. K. 1999. Biology of dairy cows during the transition period: the final frontier? J. Dairy Sci. 82:2259-2273.

Drackley, J. K., M. Heather, G. Dann, N. Douglas, N. A. Janovick Guretzky, N. B. Litherland, J. P. Underwood, and J. J. Loor. 2005. Physiological and pathological adaptations in dairy cows that may 
increase susceptibility to periparturient diseases and disorders. Ital. J. Anim. Sci. 4:323-344.

Duffield, T. F., D. F. Kelton, K. E. Leslie, K. D. Lissemore, and J. H. Lumsden. 1997. Use of test day milk fat and milk protein to detect subclinical ketosis in dairy cattle in Ontario. Can. Vet. J. 38:713-718.

Emery, R. S., J. S. Liesman, and T. H. Herdt. 1992. Metabolism of long chain fatty acids by ruminant liver. J. Nutr. 122:832-837.

Fleischmann, M., and P. B. Iynedjian. 2000. Regulation of sterol regulatory-element binding protein 1 gene expression in liver: Role of insulin and protein kinase B/cAkt. Biochem. J. 349:13-17.

Greenfield, R. B., M. J. Cecava, and S. S. Donkin. 2000. Changes in mRNA expression for gluconeogenic enzymes in liver of dairy cattle during the transition to lactation. J. Dairy Sci. 83:1228-1236.

Grum, D. E., J. K. Drackley, R. S. Younker, D. W. LaCount, and J. J. Veenhuizen. 1996. Nutrition during the dry period and hepatic lipid metabolism of periparturient dairy cows. J. Dairy Sci. 79:1850-1864.

Grummer, R. R. 1993. Etiology of lipid-related metabolic disorders in periparturient dairy cows. J. Dairy Sci. 76:3882-3896.

Hachenberg, S., C. Weinkauf, S. Hiss, and H. Sauerwein. 2007. Evaluation of classification modes potentially suitable to identify metabolic stress in healthy dairy cows during the peripartal period. J. Anim. Sci. 85:1923-1932.

Hammon, H. M., S. N. Sauter, M. Reist, Y. Zbinden, C. Philipona, C. Morel, and J. W. Blum. 2003. Dexamethasone and colostrums feeding affect hepatic gluconeogenic enzymes differently in neonatal calves. J. Anim. Sci. 81:3095-3106.

Hanson, R. W., and F. J. Ballard. 1967. The relative significance of acetate and glucose as precursors for lipid synthesis in liver and adipose tissue from ruminants. Biochem. J. 105:529-536.

Hartwell, J. R., M. J. Cecava, and S. S. Donkin. 2001. Rumen undegradable protein, rumen-protected choline and mRNA expression for enzymes in gluconeogenesis and ureagenesis in periparturient dairy cows. J. Dairy Sci. 84:490-497.

Ingvartsen, K. L., R. J. Dewhurst, and N. C. Friggens. 2003. On the relationship between lactational performance and health: Is it yield or metabolic imbalance that cause production diseases in dairy cattle? A position paper. Livest. Prod. Sci. 83:277-308.

Janovick, N. A., J. J. Loor, H. M. Dann, H. A. Lewin, and J. K. Drackley. 2004. Characterization of changes in hepatic expression of inflammation-associated genes during the peripartum period in multiparous Holstein cows using quantitative real time-PCR (RTPCR). J. Dairy Sci. 87(Suppl. 1):460. (Abstr.)

Jorritsma, R., H. Jorritsma, Y. H. Schukken, and G. H. Wentink. 2000. Relationship between fatty liver and fertility and some periparturient diseases in commercial dutch dairy herds. Theriogenology 54:1065-1074

Jorritsma, R., H. Jorritsma, Y. H. Schukkenc, P. C. Bartlettd, Th Wensinga, and G. H. Wentink. 2001. Prevalence and indicators of post partum fatty infiltration of the liver in nine commercial dairy herds in The Netherlands. Livest. Prod. Sci. 68:53-60.

Kadarmideen, H. N., P. Rohr, and L. L. G. Janss. 2006. From genetical genomics to systems genetics: Potential applications in quantitative genomics and animal breeding. Mamm. Genome 17:548-564.

Kessel, S., M. Stroehl, H. H. D. Meyer, S. Hiss, H. Sauerwein, F. J Schwarz, and R. M. Bruckmaier. 2008. Individual variability in physiological adaptation to metabolic stress during early lactation in dairy cows kept under equal conditions. J. Anim. Sci 86:2903-2912.

Kim, S., I. Sohnb, J. Ahna, K. Leea, Y. S. Leec, and Y. S. Lee. 2004 Hepatic gene expression profiles in a long-term high-fat diet-induced obesity mouse model. Gene 340:99-109.

Klucinski, W., E. Miernik-Degorska, A. Degorski, A. Targowski, and A. Winnicka. 1988. Effect of ketone bodies on the mitogenic response of bovine milk lymphocytes. Zentralbl. Veterinarmed. A 35:626-631.

Knight, C. H., D. E. Beever, and A. Sorensen. 1999. Metabolic loads to be expected from different genotypes under different systems. Metabolic Stress in Dairy Cows. Occasional Publication No. 24:27-36. Br. Soc. Anim. Sci., Edinburgh, UK.
Koundakjian, P. P., and A. M. Snoswell. 1970. Ketone body and fatty acid metabolism in sheep tissues: 3-Hydroxybutyrate dehydrogenase, a cytoplasmic enzyme in sheep liver and kidney. Biochem. J. 119:49-57.

Loor, J. J., H. M. Dann, R. E. Everts, R. Oliveira, C. A. Green, N A. Janovick-Guretzky, N. Litherland, S. L. Rodriguez-Zas, H. A. Lewin, and J. K. Drackley. 2006. Plane of nutrition prepartum alters hepatic gene expression and function in dairy cows as assessed by longitudinal transcript and metabolic profiling. Physiol. Genomics 27:29-41.

Loor, J. J., H. M. Dann, R. E. Everts, R. Oliveira, C. A. Green, N. A. Janovick Guretzky, S. L. Rodriguez-Zas, H. A. Lewin, and J. K. Drackley. 2005. Temporal gene expression profiling of liver from periparturient dairy cows reveals complex adaptive mechanisms in hepatic function. Physiol. Genomics 23:217-226.

Loor, J. J., R. E. Everts, M. Bionaz, H. M. Dann, D. E. Morin, R. Oliveira, S. L. Rodriguez-Zas, J. K. Drackley, and H. A. Lewin., 2007. Nutrition-induced ketosis alters metabolic and signaling gene networks in liver of periparturient dairy cows. Physiol. Genomics 32:105-116. doi:10.1152/physiolgenomics.00188.2007

Lopes-Cardozo, M., I. Mulder, F. van Vugt, P. G. C. Hermans, S. G. van den Bergh, W. Klazinga, and E. de Vries-Akkerman. 1975. Aspects of ketogenesis: Control and mechanisms of ketone-body formation in isolated rat liver mitochondria. Mol. Cell. Biochem. 9:155-173.

Morris, S. M. Jr. 1992. Regulation of enzymes of urea and arginine synthesis. Annu. Rev. Nutr. 12:81-101.

Murondoti, A., R. Jorritsma, A. C. Beynen, T. Wensing, and M. J. H. Geelen. 2004. Unrestricted feed intake during the dry period impairs the postpartum oxidation and synthesis of fatty acids in the liver of dairy cows. J. Dairy Sci. 87:672-679.

Nadal, A., P. F. Marrero, and D. Haro. 2002. Down-regulation of the mitochondrial 3-hydroxy-3-methylglutaryl-CoA synthase gene by insulin: The role of the forkhead transcription factor FKHRL1. Biochem. J. 366:289-297.

Ness, G. C., and C. M. Chambers. 2000. Feedback and hormonal regulation of hepatic 3-hydroxy-3-methylglutaryl coenzyme A reductase: The concept of cholesterol buffering capacity. Proc. Soc. Exp. Biol. Med. 224:8-19.

Nielsen, N. C., and S. Fleischer. 1969. B-hydroxybutyrate dehydrogenase: Lack in ruminant liver mitochondria. Science 166:10171019

Reynolds, C. K., P. C. Aikman, B. Lupoli, D. J. Humphries, and D. E. Beever. 2003. Splanchnic metabolism of dairy cows during the transition from late gestation through early lactation. J. Dairy Sci. 86:1201-1217

Reynolds, C. K., H. F. Tyrrell, and P. J. Reynolds. 1991. Effects of diet forage-to-concentrate ratio and intake on energy-metabolism in growing beef heifers-Net nutrient metabolism by visceral tissues. J. Nutr. 121:1004-1015.

Rukkwamsuk, T., T. Wensing, and M. J. H. Geelen. 1999. Effect of fatty liver on hepatic gluconeogenesis in periparturient dairy cows. J. Dairy Sci. 82:500-505.

SAS Institute. 2001. SAS User's Guide: Statistics. Version 8 edition. SAS Inst. Inc., Cary, NC.

Sauerwein, H., U. Heintges, M. Hennies, T. Selhorst, and A. Daxenberger. 2004. Growth hormone induced alterations of leptin serum concentrations in dairys cows as measured by a novel enzyme immunoassay. Livest. Prod. Sci. 87:189-195.

Steffensen, K. R., and J. Gustafsson. 2004. Putative metabolic effects of the liver X receptor (LXR). Diabetes 53(Suppl. 1):S36-S42.

Strang, B. D., S. J. Bertics, R. R. Grummer, and L. E. Armentano. 1998. Effect of long-chain fatty acids on triglyceride accumulation, gluconeogenesis and ureagenesis in bovine hepatocytes. J. Dairy Sci. 81:728-739.

Suriyasathaporn, W., A. J. Daemen, E. N. Noordhuizen-Stassen, S. J. Dieleman, M. Nielen, and Y. H. Schukken. 1999. Beta-hydroxybutyrate levels in peripheral blood and ketone bodies supplemented in culture media affect the in vitro chemotaxis of bovine leukocytes. Vet. Immunol. Immunopathol. 68:177-186. 
Van den Top, A. M., M. J. H. Geelen, T. Wensing, G. H. Wentink, A. T. H. van 't Klooster, and A. C. Beynen. 1996. Higher postpartum hepatic triacylglycerol concentrations in dairy cows with free rather than restricted access to feed during the dry period are associated with lower activities of hepatic glycerolphosphate acyltransferase. J. Nutr. 126:76-85.

van Dorland, H. A., S. Richter, I. Morel, M. G. Doherr, N. Castro, and R. M. Bruckmaier. 2009. Variation in hepatic regulation of metabolism during the dry period and in early lactation in dairy cows. J. Dairy Sci. 92:1924-1940.

Vicari, T., J. J. G. C. van den Borne, W. J. J. Gerrits, Y. Zbinden, and J. W. Blum. 2008. Postprandial blood hormone and metabolite concentrations influenced by feeding frequency and feeding level in veal calves. Domest. Anim. Endocrinol. 34:74-88.

Voet, D., and J. G. Voet. 2004. Fundamentals of Biochemistry. 3rd ed. John Wiley and Sons, New York, NY.
$\mathrm{Xu}$, C., and Z. Wang. 2008. Comparative proteomic analysis of livers from ketotic cows. Vet. Res. Commun. 32:263-273.

Zammit, V. A. 1983. Regulation of hepatic fatty acid oxidation and ketogenesis. Proc. Nutr. Soc. 42:289-302.

Zammit, V. A. 1990. Ketogenesis in the liver of ruminants-Adaptations to a challenge. J. Agric. Sci. (Camb.) 115:155-162.

Zammit, V. A. 1996. Role of insulin in hepatic fatty acid partitioning: Emerging concepts. Biochem. J. 314:1-14.

Zelcer, N., and P. Tontonoz. 2006. Liver X receptors as integrators of metabolic and inflammatory signaling. J. Clin. Invest. 116:607614

Zhu, L. H., L. E. Armentano, D. R. Bremmer, R. R. Grummer, and S. J. Bertics. 2000. Plasma concentration of urea, ammonia, glutamine around calving, and the relation of hepatic triglyceride, to plasma ammonia removal and blood acid-base balance. J. Dairy Sci. $83: 734-740$ 